\title{
Easing the transition from school to HE: scaffolding the development of self- regulated learning through a dialogic approach to feedback.
}

\author{
Chris Beaumont*, Susan Canning, Claire Moscrop. \\ Edge Hill University, Ormskirk, UK \\ Abstract
}

\begin{abstract}
High quality feedback is known to be essential for learning, yet in higher education it has been highlighted as a problem area in the UK by both the Quality Assurance Agency (QAA) and National Student Surveys. Furthermore, a recent study has shown that there is a fault-line between the highly structured guidance system that exists in schools/colleges and the culture of 'independent' learning that is promoted in higher education and suggests that this is a significant barrier to a successful transition.

This article reports research to improve the transition for first year undergraduates by providing a structured set of guidance activities as a means of an extended induction into the assessment processes in higher education. The activities are based on the Dialogic Feedback Cycle which encompasses principles of feedback as dialogue, emphasising guidance at the start of, and during an assignment rather than summative written feedback. The intervention was evaluated by means of a questionnaire and supported by focus groups. The questionnaire was administered to a control group and an intervention group. Results showed statistically significant improvements $(p<0.05)$ in students' perceptions of their understanding of assessment tasks, criteria, and confidence at completing assessment tasks and self-regulated learning.
\end{abstract}

\section{Keywords}

Feedback, Feedforward, Dialogical Feedback Cycle DFC, Assessment, Self-regulated learning, transition, computing.

\section{Introduction}

The transition from school to higher education is increasingly recognised to constitute a crosscultural process 'with potential for substantial problems' (Kirkpatrick and Mulligan, 2002, 75) and experienced as an 'alien environment' (Askham, 2008). There can be many reasons for such problems and Lawrence (2005) provides a detailed analysis of the complexities of the cultural transition in terms of socio-cultural competencies, university (learning) literacies and selfmanagement. However, a particularly important aspect concerns assessment practices and feedback. Beaumont, O’Doherty and Shannon (2011) identified the substantial difference between the approaches for assessment feedback at school and higher education as a significant barrier to successful transition. Their study of students' experiences in English schools and

\footnotetext{
*Email:Chris.Beaumont@Edgehill.ac.uk
} 
universities revealed that both students and teachers used the term 'spoon feeding' to describe the learning process in school, explaining that it aims to deliver high grades. Whilst this may be good for league tables, it leaves many students unprepared for university assessment, which is typically characterised as 'independent learning' (Leese, 2010). Bingham and O’Hara (2007) confirm the difficulty students have in becoming 'autonomous' learners.

It is therefore important to explore the effectiveness of approaches that will help students make a successful transition between the two sectors; in short, to scaffold the development of self-regulated learning skills. Indeed Evans' (2013, p73) review of research on assessment feedback notes the 'paucity of the empirical evidence of what type of feedback works'. This research is a response to these imperatives, and evaluates a systematic and theoretically-based intervention which guides the student from the familiar school system towards increased selfregulation demanded in higher education.

The remainder of this paper outlines the underpinning research in assessment feedback and subsequently explains the methodology and intervention activity in sufficient detail to provide transparency and enable readers to assess the relevance of the approach to their own context. This is followed by an analysis of the results and a critical discussion of the findings, together with recommendations for further improvements.

\section{Assessment Feedback in Higher Education}

Assessment is the key activity which defines the curriculum in students' eyes (Ramsden, 2003) and has a major influence on their learning (Biggs, 2003). However, assessment alone is not good enough for effective learning (Gibbs \& Simpson, 2004) and it is generally accepted that constructive feedback is essential for improving performance (Shute, 2008). Indeed Laurillard (2002, p.55) claims that 'action without feedback is completely unproductive for a learner' and it 


\section{Beaumont et al.}

has been shown that 'high quality feedback is the most powerful single influence on student achievement' (Hattie, 1987; Black and Wiliam, 1998). Supportive evidence from an extensive meta-analyses conducted by Hattie \& Timperley (2007) shows an average effect size of 0.79 on student achievement. In the higher education setting Hounsell (2007) states that feedback can enhance learning in three significant ways: by accelerating learning; by optimising the quality of what is learned; and by raising individual and collective attainment.

Despite this central and vital role in teaching and learning, assessment feedback has also become a major concern of higher education institutions in recent years since it has consistently emerged as the least satisfactory aspect of student experience in the UK National Student Surveys (Nicol, 2013). Students are not alone in their concerns, an analysis of reports of almost 3000 quality assurance visits over an eight-year period reveals that the QAA reviewers had commented on the "failure of a significant number of institutions to provide adequate feedback on students' work' (QAA, 2003, p 28).

Research has yielded plenty of principles for good practice in assessment and feedback (Gibbs \& Simpson, 2004; Nicol \& Macfarlane-Dick, 2006; Shute, 2008; Hattie \& Timperley, 2007). Whilst these are undeniably useful, they do not conceptualise feedback in any systemic way within the assessment process, it is left to the teacher to makes sense of how to incorporate them in their particular context.

A recent shift in the conceptualisation of feedback is described by Molloy and Boud (2013) who argue that students should not be passive recipients of teachers' comments (transmission model) but they should be central to the feedback process, taking an active role. Such activity involves dialogue to enable students to explore, clarify and internalise assessment criteria and standards - a possible route to self-evaluative expertise and the holy grail of 
'sustainable feedback' (Sadler, 2010). This dialogue can be with peers or teachers so long as it is focussed on future improvement. Burke (2011) attacks the problem through a structured formbased approach to promote effective dialogue between tutor and student around the feedback which has been provided on an assessed task, an approach which formalises and enforces reflection and conversation with an expert in order to stimulate students' engagement with, and action upon the guidance provided.

Theories and frameworks that connect these concepts in a systematic way are thin on the ground. A recent approach which models assessment feedback as a guidance system, known as the Dialogic Feedback Cycle (DFC) (Fig 1) is provided by Beaumont, O’Doherty and Shannon (2011). This is particularly interesting and appropriate as it incorporates the recent ideas of formative dialogue, engagement with criteria and student activity. It meets Leese's(2010) call for structured activities and more academic support and models the feedback process as 3 stages, each of which is also shown as a cycle, emphasising the importance of iterative dialogue, principally between teacher and student. It also addresses the criticism that courses are characteristically 'end loaded' with summative feedback that is often irrelevant or too late to be of practical use (Hounsell, 2007) since it emphasises the guidance provided during the process of assessment. Furthermore, the DFC is empirically based on a qualitative study of 176 students in 6 schools/ FE colleges and 3 universities and it provides a representation of the systemic guidance that the students experienced in schools. Thus, it comprises activities with which students are familiar, and therefore provides a good starting point.

However, this presents a stark contrast to students' first year university experiences reported in Beaumont, O'Doherty and Shannon's (2011) study. It revealed inconsistent practice in higher education, students indicated that they received comparatively little formative 


\section{Beaumont et al.}

guidance, particularly at stages 1 and 2 of the cycle and that this contributed significantly to confusion regarding what was required of them, consequently causing dissatisfaction.

(Figure 1)

\section{Self-Regulated Learning}

A key characteristic of UK higher education is the emphasis placed on the responsibility of students for their learning (QAA, 2012) and therefore increased self-reliance needs to be one of the aims of a successful transition from school to HE. The term 'independent learning' is often used, but is not well defined and Kesten $(1987, \mathrm{p} 9)$ identifies a wide range of synonyms such as “autonomous learning, independent study, self-directed learning, student initiated learning, project orientation, discovery and inquiry, teaching for thinking, learning to learn, selfinstruction and life-long learning”. Furthermore, it has undertones of isolation (Knight 1996), which is in conflict with the importance of dialogue in learning (Alexander,2008). Perhaps a more appropriate aim would be self-regulated learning (SRL), for which Zimmerman and Schunk (2004) provide a well-developed model comprising three stages: forethought, performance and self-reflection. At each stage they identify learner activities, such as goal setting, cognitive monitoring and self-evaluation which we would consider exemplify desired student approaches to learning in university. These stages and activities are closely aligned to those identified in the DFC and this suggests that an adapted DFC may be a suitable method of helping students to develop SRL skills.

In order to ease the transition from school to higher education, we consider that the first year curriculum of university needs to change by weaning students off 'spoon feeding' towards self-regulated learning. We hypothesised that this can be scaffolded by adapting the DFC, with 
high levels of guidance at the start of the year, gradually reducing (fading) as students gain experience. By using this approach we planned to help the student transition by starting with a familiar system which included high levels of formative activities. Furthermore, by incorporating high levels of discussion we intended to promote students' understanding of the standards required-an essential prerequisite for good performance (Sadler, 1989). Additionally, a study by Whitfield et al, (2008) showed promising results by adopting this approach to improve the writing skills of computing undergraduates; we therefore wanted to test the DFC by applying it in a broader context than academic writing.

Evans (2013, p73) points out that there is ' little systematic empirical evidence on what type of feedback is best for what situations' and therefore we aim to help address this deficiency by conducting a systematic test of the DFC.

\section{Aim}

The aim of this research was therefore to evaluate the Dialogic Feedback Cycle (DFC) as a means of transitioning students from a high dependency culture to self-regulated learning culture.

\section{Methodology}

The researchers are HE tutors of first-year students and who are acutely aware of the problem outlined above. They were keen to design and systematically evaluate an intervention to improve the students' experience of assessment feedback within their own practice. The approach is situated in the Action Research (AR) tradition, being characterised by 'self-reflective enquiry' to understand, improve and reform practice (Carr \& Kemmis, 1986) (Ebbutt, 1985). Whilst the motivation was primarily to improve students' learning and experience, there was also a dimension that sought to involve students in dialogue with their tutors in a community of 


\section{Beaumont et al.}

practice rather than mere recipients of tutors' collective wisdom. The research followed a 4-stage AR model of planning the intervention using the DFC; implementing it; collecting data and evaluating / reflecting on the results (Cohen, Manion \& Morrison, 2007). These are elaborated in the rest of this article. Ethical approval was gained from the Faculty ethics committee, students received written and verbal briefings of the purpose of the research and normal consent procedures were used prior to collecting data, which was anonymised.

A first year module (Systems Analysis) was selected since it was taught by the team of tutor-researchers and it runs throughout the first year of the BSc Computing degree. It was modified by the tutors to incorporate activities at each stage of the DFC and the model of good practice from Nicol \& McFarlane-Dick (2006); these are detailed in the next section. The new design was evaluated by students and tutors over the period of the academic year. A 'cycle in cycle' reflective approach was undertaken allowing modifications to be made throughout the year.

The intervention was evaluated using a mixed methods approach to elicit the views of the entire cohort using a questionnaire, and focus groups to provide richer, illuminative detail. Initially a baseline questionnaire $(n=37,70 \%$ of the cohort responded) and semi-structured focus group which consisted of an opportunity sample $(n=8)$ were conducted with a cohort of students at the end of their first year. These students (the control group) experienced no intervention. The following cohort experienced the intervention in this module and their perceptions of their experience were evaluated using the same questionnaire ( $n=43,86 \%$ of the cohort) and focus group (n=8). The two cohorts' characteristics (age on entry, entry qualifications) were analysed using a 2-tailed t-test for independent samples. Table 1 shows means and standard deviation for 
the control and intervention group and show no statistically significant difference. Summative assessment results were also compared for the cohorts.

(Table 1)

The questionnaire used a 5-point Likert scale to explore students' experience of feedback in the module, their confidence levels for learning and completing assignments independently and their normative views about feedback at university. The focus group enabled us to explore responses in more detail. The questionnaire data were ordinal, consequently they were analysed for significance using the Mann-Whitney U-test rather than more usual t-test to check for significant changes in perceptions. Assessment results for the two cohorts were also compared and tested for significance using the one-tailed t-test. Focus group data were transcribed and used as a supplementary source to illuminate the statistics.

\section{Intervention}

The module tutors identified specific activities associated with the stages of the DFC that they considered appropriate for this module:

- Preparatory Guidance stage: Discussion and construction of assessment criteria and student marking of exemplars. This was aimed at helping students to fully understand criteria by actively applying them to similar work, an approach advocated by Rust (2003).

- In-task guidance stage: Students submitted a single draft of their work for formative tutor feedback. This was intended to pick up major misconceptions early and help students develop confidence in their work. Using in-task feedback enables the student to scaffold their learning towards the completion of the assignment. Bransford, Brown and Cocking (2000) identify this type of scaffolding as important for various reasons, including highlighting critical features of discrepancies from the ideal solution. 


\section{Beaumont et al.}

- Performance feedback stage: In addition to normal written feedback, all students received 1:1 session with the module leader in order to clarify verbally any misunderstandings and allow them to raise questions. Interestingly, the NUS Student Experience Report (2008) stated that $71 \%$ of students wanted verbal feedback on coursework in an individual meeting but only $25 \%$ were given such an opportunity, so we expected this approach to have a positive influence on both the students' performance and their motivation.

These activities placed additional emphasis on the first two stages of the DFC. Prior to the intervention, the module assessment consisted of one formative assessment and two summative assignments in semester $1 \& 2$ respectively. Students were supported by in-class exercises and a formative coursework which underpinned the theory, methods and practices demanded in the summative assessment. There was no formal draft submission of coursework. Once the assessment was submitted the student would receive the assessment back, usually within three weeks, with their mark or grade and comments, written on the front cover which is used as a feedback sheet.

The new design incorporated a formative assessment (presentation) in the first two weeks of semester 1 , followed by the same summative assignments as in the previous model. Table 2 shows how the activities were scheduled in the first semester after the redesign to align formative activities to the DFC; it also shows links to the principles of good feedback practice (Nicol and MacFarlane-Dick, 2006). The course team found this table to be a useful planning tool. (Table 2)

\section{Formative assignment}

In order to engage students as quickly as possible with HE criteria, a purely formative presentation assignment was conducted in weeks 1-3. This employed several of the activities 
from the DFC, with the emphasis on preparatory guidance and performance feedback. In week one, groups of students discussed what they thought would make a good or bad presentation and documented their conclusions. They subsequently constructed criteria which were shared in a plenary and a consensual set of criteria were developed. Students were then shown video exemplars of presentations submitted by the previous year group which they marked with the common criteria. The students discussed their assessment of the exemplars and reached consensus on a grade.

In week two the students delivered their own presentations. The subject was linked to careers; the title was "My Perfect Job". In small groups, the students delivered a five minute presentation. At the end of the presentation the students spoke about how they felt presenting and whether they thought they had met the assessment criteria (self-assessment). The class as a whole then assessed the presentation using the criteria they had developed previously and gave feedback (peer-assessment).

At the same time as the peer assessment was taking place, the tutor also marked each student using a formal mark sheet using the criteria the students had developed and at the end of the session, gave one to one feedback on their presentation. Students used the feedback sheet as part of their personal development plan portfolio. The portfolio includes reflections on feedback and activities with action plans for future improvement.

The module tutors considered that the peer marking of the presentations worked extremely well. The students were all engaged with the development of the criteria and they were extremely critical of the presentations that they watched and marked. They clearly demonstrated good understanding of criteria for a presentation. Tutors also considered that the presentations were much better than previous years. In the control group the average tutor-given mark of this 


\section{Beaumont et al.}

formative assessment was 55\%. The average mark for the intervention group was $72 \%$. In general, there was close agreement between the tutor's and peer assessed marks. Any substantial discrepancy was discussed by the class until a consensus was reached.

\section{Summative Assignment}

The next section explains how the DFC was used to structure guidance for the subsequent summative coursework assignment.

\section{DFC Model-Preparatory Guidance}

Preparatory guidance was deemed to be critical for developing student understanding of what constitutes of good performance. Consequently, activities involving student marking of exemplars and discussion of criteria were used whenever an assignment was distributed.

The students again discussed assessment criteria for the first summative assignment in week four. However, this time the criteria (relating to a feasibility study) were tutor-generated since students did not yet possess the knowledge to construct meaningful criteria on this subject. Students examined the assessment criteria and applied them by marking 'good' and 'bad' exemplars of sections from previous coursework. A subsequent discussion took place to clarify issues that arose. This assessment task was considered unsuccessful by students and tutors; students explained that they found it confusing to apply criteria to a section of an assignment since it lacked the context provided by the entire piece of work. Tutors also speculated that students did not have the knowledge to interpret these criteria effectively.

\section{DFC Model- In Task Guidance}

In week ten students were given the opportunity to submit a draft of the (partially complete) coursework in progress. In semester one this submission was optional and the uptake was just $42 \%$. Further investigation showed that the submission coincided with summative assignments in 
other modules, and that the lead time from setting the work to submission of the draft was also considered too short. Subsequent drafts were made compulsory, and further consideration was taken with scheduling to improve their utility. The drafts were then used to enable tutors to provide formative feedback and to monitor the students' progress.

We considered that the submission of a draft was especially important in semester one since this constituted their first university assignment. To ensure students could apply the feedback to this assignment, tutors provided both written and verbal guidance within one week of submission. In addition, frequent opportunities were provided for tutor and peer dialogue throughout the assignment and students were encouraged to approach the tutor at any stage for advice about their coursework. Verbal feedback was given after the submission of drafts as tutors felt that the student responded better to this than the written feedback and most importantly it also promoted a two way dialogue regarding the student's learning. The student could ask any questions about the feedback they were given which developed a greater understanding of the standard required at level 4 . The feedback given to the students was generally positive with the most important weaknesses highlighted. Each student was given improvement targets for the following coursework.

\section{DFC Model-Performance Feedback}

Tutors provided written feedback which consisted of comments and a mark; they considered it particularly important to link the mark, feedback and criteria as a means of explaining the standard. Additionally, strengths, weaknesses and points for improvement were highlighted to enable the student to use the feedback in a positive way within the subsequent coursework. This was intended to provide motivation and increase student self-esteem. Individual verbal feedback was also provided enabling the tutor and student to discuss each student's academic progress 


\section{Beaumont et al.}

within the module and provided further opportunity for clarification. Action points were identified for the student for the next coursework. This was intended to enable the student to apply effectively the feedback they had been given.

To promote further the students' self-assessment ability, they submitted a self-assessment mark sheet alongside their coursework. Most students (58\%) underestimated their mark but 38\% were within $+/-10 \%$ of the tutor's mark and $28 \%$ were within $5 \%$. These data provided useful feedback for the module tutor and provided excellent opportunity for 1:1 verbal discussion.

We also found that the inclusion of formative activities and additional guidance opportunities benefitted the tutor since they provided information about student progress which they used to review the material and improve upon it for example through a different in-class exercise or activity.

\section{Analysis of Results}

\section{Student perceptions of criteria}

One of the aims of the research was to prepare students for assessment by improving their understanding of what constituted good performance and hence self-assessment skills. In the intervention group students prepared their own assessment criteria for a given topic (a presentation) and marked presentations using those criteria. Students were also walked through the assessment criteria for their summative coursework to promote understanding of what constituted good performance. Finally, students were given exemplars of previous assessments and were asked to mark it using the given assessment criteria. None of this intervention was in place for the control group who were simply given the assessment criteria with the assignment. Four of the questionnaire statements related to this topic. These are shown in table 3.

(Table 3) 
The first two statements showed a significant positive change $(\mathrm{p}<0.05)$ with a medium effect size. Statement three also showed a significant improvement, though with a small effect size. The fourth statement showed no significant change, however, the control group result was already at $90 \%$ for this statement so a significant positive change would have been difficult.

\section{Perceptions of feedback}

In the questionnaire there were specific questions about draft assignments and general perceptions. Results relating to feedback on draft assignments were wholly positive with significant changes between the cohorts. The questionnaire statements relevant to this aspect are shown in table 4 . Whilst the control group had the informal opportunity to submit drafts, their importance was emphasised in the intervention group by explicitly building them into the assessment timetable which positively encouraged submission. The results show this intervention had a significant positive effect with medium effect size. Interestingly, while the students in the focus group all stated that drafts had been useful, there was some resistance to compulsory drafts:

"No it should be up to you how you structure your time ...so I don't know why they would say it is a compulsory draft"

"I'm not sure if that was fair or not"

(Table 4)

Feedback in the control group was limited to written comments throughout an assignment with general comments on the front summary sheet. Verbal feedback was only given when the student asked for it. In the intervention group, students received the same quality written feedback and every student also received 1:1 verbal feedback from the tutor in class time. Focus groups identified the benefits: 
"Because it depends how you interpret their [written] words doesn't it? They can explain their words with verbal"

The results regarding general feedback were mixed. Ten statements from the questionnaire were relevant to this aspect of the research. Table 5 shows the statements with the corresponding results. Six showed a significant positive change; five with medium effect sizes: These referred to: feedback was encouraging; timeliness; providing opportunity for discussion; helpfulness in learning; willingness to ask tutor; use in preparation of next work. One was borderline: receiving detailed feedback $(\mathrm{p}=0.057)$.

Three showed no significant change: I understood the feedback; Feedback related to criteria; feedback was detailed; feedback enabled me to understand the mark. The results from the control group were already over $80 \% \mathrm{~A} / \mathrm{SA}$ for these three statements. (Table 5)

\section{Students' self-regulated learning skills}

One of the aims of the research was to improve students' confidence in their ability to work independently. The results from the questionnaires show a statistically significant change between the two cohorts. All five statements in the questionnaire which related to this factor had a significant positive change with medium effect size; these statements are shown in table 6 .

\section{(Table 6)}

\section{Assessment results.}

Self-reported ratings are useful indicators of student confidence and perceptions, but ideally we would like measures of independent learning and the effectiveness of students' strategies. At this stage we have not developed objective indicators for these specific competencies. It is, however instructive to consider if there have been any changes in assessment grades as a result of the 
intervention. Given that the level of support has increased, we hypothesise that there will be an improvement.

Descriptive statistics are shown in Table 7 and a bar chart showing the distribution of marks is shown in Figure 2. Coursework 1 marks improved and a 1-tailed t-test yields $t_{(102)}=-$ 1.488, $\mathrm{p}=0.068$. While this is not significant at the conventional $5 \%$ level, it is encouraging. However, possibly a more interesting finding is the $50 \%$ increase in the standard deviation, demonstrating an increased spread of marks, with $50 \%$ students scoring $>60 \%$ in the intervention group, compared to $32 \%$ in the control group. As a comparison, assessment results for the two cohorts were compared in other modules where the intervention had not taken place. In each module a small decrease in mean mark occurred from the control to the intervention group. While this was not statistically significant: (module $\mathrm{A}$ : $\mathrm{t}_{(102)}=1.63, \mathrm{p}=0.110$; Module $\mathrm{B}$ : $\mathrm{t}$ $(102)=0.54, \mathrm{p}=0.586)$ it supports the likelihood that the cohorts were equivalent.

Coursework 2 was a group assignment conducted in semester 2 . In this case the mean mark reduced slightly between the control and intervention groups, though this is not significant, $\left.\mathrm{t}_{(102)}=0.72, \mathrm{p}=0.235\right)$. The standard deviation almost doubled.

(Table 7)

(Figure 2)

\section{Discussion}

In this paper we have evaluated an intervention aimed at easing the transition from a highly supported guidance system at school towards a self-regulated learning approach at university. Leese (2010) suggested that structured guidance during assessment tasks would be beneficial and the DFC met these requirements. It included activities for students to develop self-assessment abilities (Sadler, 2010) by applying assessment criteria to exemplars, receive feedback on a draft assignment and engage in discussion at all stages, including 1:1 sessions on their summative 


\section{Beaumont et al.}

work. Whilst these activities were familiar, they were not as intensive or directive as those employed at school. For example, one draft assignment was permitted, whereas Beaumont O’Doherty and Shannon (2011) report that schools often allow multiple drafts of assignments. This approach is therefore an attempt to scaffold the transition to a more self-regulated learning approach.

Our results are encouraging in a number of ways. Statistically significant improvements $(\mathrm{p}<0.05)$ were achieved in several important aspects. The focus on criteria yielded better understanding of the criteria and what was expected in the assignment. Furthermore, students agreed that feedback was timely enough to be useful, it helped their learning and they used it to prepare for the next assignment. A pleasing result is that students were more willing to ask tutors for help and they had gained confidence to plan, research and apply knowledge in a more independent way. These are clear indicators of development in self-regulated learning abilities and we conclude that adopting the DFC as a model has been effective in those respects - the improved levels of confidence show a more successful transition to the 'alien world' of HE.

When taken in conjunction with the assessment results, there is a less clear picture. A striking feature is the contrast between the confidence levels expressed by the students and their achievement. In coursework 1 some $28 \%$ of students achieved a mark lower than $50 \%$, yet $90 \%$ or more of students claimed to understand fully the criteria and what constituted a good performance with $75 \%$ of students claiming to fully understand what to do at the start. While we do not equate assessment performance with effective self-regulated learning, we do consider that this is a disappointing result. However a comment expressed in a focus group may cast some light on this finding. In common with many UK universities, first year results do not count 
towards degree classification at this university, students in a focus group considered that this was 'demotivating' and they saw little benefit in striving for higher marks.

Furthermore, whilst there was a slight improvement in grades in the first coursework, (significant at the $7 \%$ level) this was not maintained in the second semester. There are a number of variables that may have contributed to this outcome: guidance was more intensive during the first assignment and students were working individually; tutors also perceived that the interest and motivation levels had reduced towards the end of the year. The motivational factors that are involved are likely to be complex, though we suspect that there is a stronger performance-related extrinsic motivational culture at school than at university, a further aspect of the culture gap.

Despite these reservations, we consider that there is sufficient evidence to incorporate principles from the DFC into other first year modules, increasing the emphasis on stage $1 \& 2$ activities. This will provide improved consistency of experience and reinforce the principles of self-regulated learning, helping students develop, through practice, the self-assessment capabilities that Sadler (2010) considers essential. In particular, all modules will be redesigned to include activities which engage students with criteria using exemplars to model standards, provide in-task formative guidance suitable for the subject and deliver verbal in addition to written performance feedback.

Within the Action Research framework, the module tutors have identified a number of refinements which will be applied and evaluated in the next presentation of the module. Firstly, the importance of feedback and guidance will be raised by allocating more time within seminars. Secondly, feedback will include specific action points to help students improve, focus on improvement, and identify how it can be also be applied in other modules to promote a systemic view of learning the discipline. Thirdly, while the exemplars were useful, they need to include 


\section{Beaumont et al.}

context to make them meaningful. Fourthly, attention will be paid to the sequencing of both formative and summative coursework to avoid submission bottlenecks and try to avoid lastminute surface approaches. Finally, whilst in this intervention we provided formative assessment support, there was little explicit teaching of key aspects of self-regulation such as goal-setting, planning, monitoring and self-instruction and we consider that this is an important further component for inclusion in the future.

This article has provided details of an Action Research project that sought to improve students' transition from school to university by providing structured guidance and feedback processes. Given the sample size and restriction to a single subject area we are not suggesting these are widely generalizable. Instead, by presenting details of this intervention, with evidence of their effect in this context we seek to offer sufficient transparency that readers will be able to determine if and how to adapt them in their own situation.

\section{Acknowledgements}

We would like to extend sincere thanks to all the students and staff who helped in this project and the Write Now CETL and the Centre for Learning \& Teaching Research at Edge Hill University for funding the research and to Alma Whitfield (Liverpool Hope University) for sharing details of activities from previous work.

\section{References}

Alexander, R.J. 2008 Towards Dialogic Teaching: rethinking classroom talk, 4th ed. York: Dialogos.

Askham, P. 2008. Context and identity: Exploring adult learners' experiences of higher education. Journal of Further and Higher Education 32, (1): 85-97.

Beaumont, C, Michelle O. O’Doherty, and Lee Shannon. 2011. Reconceptualising assessment feedback: A key to improving student learning. Studies in Higher Education 36,(6) : 117.

Biggs, J. 2003. Teaching for Quality Learning at University. 2nd Ed. Buckingham: Society for Research into Higher Education and Open University Press

Bingham, R. and O'Hara, M. 2007. Widening participation in early years degrees: 'I realised I could, and would, do this - and I have!'. Journal of Further and Higher Education, 31(4): 311-21.

Black, P. \& Wiliam, D. 1998 Assessment and classroom learning. Assessment in Education. 5 (1) pp.7-74.

Bransford, J. D., Brown, A.L. and Cocking, R.R. 2000. How People Learn, Brain, Mind, Experience and School, Washington DC: National Academy Press. 
Burke, D. 2011. Now I've got the feedback, what do I do with it? Strategies For Students to Get More Out of Tutor Feedback, Practice and Evidence of Scholarship of Teaching and Learning in Higher Education, 6 (1) : 43-60.

Carr,W. and Kemmis,S. 1986. Becoming Critical. Lewes: Falmer.

Cohen, L., Manion, L. \& Morrison, K. 2007. Research Methods in Education 6th ed. Abingdon: Routledge.

Ebbutt,D. 1985. Educational action research: some general concerns and specific quibbles. In: R.Burgess (ed.) Issues in Educational Research: Qualitative Methods. Lewes: Falmer, 152-174.

Evans,C. 2013 Making Sense of Assessment Feedback in Higher Education, Review of Educational Research 83:70-120.

Gibbs, G. \& Simpson, C. 2004. Conditions under which assessment supports students' learning. Learning and Teaching in Higher Education 1 (1) : 3-31.

Hattie, J. \& Timperley, H, 2007. The Power of Feedback. Review of Educational Research 77(1): $81-112$.

Hattie, J.A. (1987) Identifying the salient facets of a model of student learning: a synthesis of meta-analyses. International Journal of Educational Research, 11 (2):187-212.

Hounsell, D. 2007. “Towards more sustainable feedback to students.” In: Rethinking Assessment in Higher Education: learning for the longer term, edited by David Boud and Nancy Falchikov, 101-113. London: Routledge.

Kesten, C. 1987. Independent learning: a common essential learning: a study completed for the Saskatchewan Department of Education Core Curriculum Investigation Project, Saskatchewan Department of Education: University of Regina ERIC\# ED292836.

Kirkpatrick, A., \& Mulligan, D. 2002. Cultures of learning: Critical reading in the social and applied sciences. Australian Review of Applied Linguistics 25 (2): 73-100.

Knight. P. (1996) Independent Study, independent studies and 'core skills' in higher education. In: Tait, J \& Knight. P. (Eds.) The management of independent learning. London: Kogan Page. Pp.29-37.

Laurillard, D. 2002. Rethinking university teaching: A conversational framework for the effective use of learning technologies. 2nd ed. London: Routledge.

Lawrence, J. 2005. Reconceptualising attrition and retention: integrating theoretical, research and student perspectives, Studies in learning, evaluation and development 2 (3): 16- 33.

Leese, M. 2010. Bridging the gap: supporting student transitions into higher education. Journal of Further and Higher Education 34 (2): 239-251.

Molloy, E and Boud,D.. 2013. "Changing conceptions of feedback" In Feedback in Higher and Professional Education, edited by David Boud and Elizabeth Molloy, 11-33. Abingdon: Routledge.

NUS. 2008. "NUS Student Experience Report", National Union of Students. [http://www.nus.org.uk/PageFiles/4017/NUS_StudentExperienceReport.pdf]

Nicol, David. 2013. "Resituating feedback from the reactive to the proactive" In Feedback in Higher and Professional Education, edited by David Boud and Elizabeth Molloy, 34-49. Abingdon: Routledge.

Nicol, D.J. \& Macfarlane-Dick, D. 2006. Formative assessment and self-regulated learning: a model and seven principles of good feedback practice, Studies in Higher Education, 31:2, 199 - 218 . 
Quality Assurance Agency. 2003. Learning from subject review, 1993-2001: Sharing good practice. Quality Assurance Agency for Higher Education.

http://www.qaa.ac.uk/reviews/

Quality Assurance Agency. 2012. UK Quality code for Higher Education, Chapter B3: Learning and Teaching, Draft for consultation May 2012. Quality Assurance Agency for Higher Education. http://www.qaa.ac.uk/Publications/InformationAndGuidance/Documents/Chapter-B3draft-consultation.pdf

subjectReview/learningfromSubjectReview/learningFromSubjectReview.pdf.

Ramsden, P. 2003. Learning to Teach in Higher Education, 2Rev (Ed.) London, Routledge.

Sadler, R. 1989. Formative assessment and the design of instructional systems, Instructional Science 18: 119-144.

Sadler, D. R. 2010. Beyond feedback: developing student capability in complex appraisal. Assessment and Evaluation in Higher Education. (35) 5 : 535-550.

Shute, V. 2008. Focus on Formative Feedback, Review of Educational Research. 78 (1) : 153189.

Whitfield, A., O’Doherty, M.O., Mony, A. \& Hetherington, R. 2008. Write IT Right: Developing Academic Writing Within The Discipline of Computing Using FeedForward Feedback. Proceedings of 9th HEA-ICS Conference. Liverpool Hope University, Liverpool. 26-28 August.

Zimmerman, B. \& Schunk, D. H. 2004. Self-regulating intellectual processes and outcomes: a social cognitive perspective, in Motivation, emotion and cognition: integrative perspectives on intellectual functioning and development, Edited by: D. Y. Dai \& R. J. Steinberg. 323-349. Mahwah, NJ: Lawrence Erlbaum. 
Table 1. Age and UCAS entry points data for control and intervention groups

\begin{tabular}{|l|c|l|l|l|l|}
\hline & $\begin{array}{l}\text { No. of } \\
\text { students }\end{array}$ & $\begin{array}{l}\text { Mean age } \\
\text { on entry }\end{array}$ & $\begin{array}{l}\text { Standard } \\
\text { deviation } \\
(\text { age })\end{array}$ & $\begin{array}{l}\text { Mean points } \\
\text { on entry }\end{array}$ & $\begin{array}{l}\text { Standard } \\
\text { deviation } \\
(\text { entry } \\
\text { points })\end{array}$ \\
\hline Control & 52 & 20.7 & 3.92 & 228 & 86.01 \\
\hline Intervention & 50 & 20.6 & 4.01 & 226 & 96.3 \\
\hline & \multicolumn{7}{|l}{$\left(\mathrm{t}_{(102)}=0.175, \mathrm{p}=0.861\right)}$. & $\left(\mathrm{t}_{(102)}=0.794, \mathrm{p}=0.431\right)$. \\
\hline
\end{tabular}


Table 2. DFC Model and Nicol model aligned to module

\begin{tabular}{|c|c|c|c|c|}
\hline DFC stage & Week & Assessment Activity & $\begin{array}{c}\text { Nicol \& } \\
\text { McFarlane- } \\
\text { Dick principles } \\
{[1-7]}\end{array}$ & DFC Activity \\
\hline $\begin{array}{l}\text { Preparatory } \\
\text { Guidance }\end{array}$ & 1 & Formative Coursework & $1,2,4,5,7$ & $\begin{array}{l}\text { Discussion of assessment } \\
\text { criteria } \\
\text { Student developed assessment } \\
\text { criteria } \\
\text { Exemplars of presentations } \\
\text { Peer Assessment of Exemplars }\end{array}$ \\
\hline $\begin{array}{l}\text { In- Task } \\
\text { Guidance }\end{array}$ & 2 & $\begin{array}{l}\text { Submit formative } \\
\text { Coursework and } \\
\text { presentation of } \\
\text { Coursework } \\
\end{array}$ & $1,2,3,5,7$ & Peer assessed presentations \\
\hline $\begin{array}{l}\text { Performance } \\
\text { Feedback }\end{array}$ & 3 & Coursework activities & $1,3,4,5,7$ & $\begin{array}{l}\text { Tutor Feedback given for } \\
\text { formative coursework }\end{array}$ \\
\hline \multirow[t]{2}{*}{$\begin{array}{l}\text { Preparatory } \\
\text { Guidance }\end{array}$} & 4 & $\begin{array}{l}\text { Summative } \\
\text { Coursework } \\
\text { handed out }\end{array}$ & $1,2,4,5,7$ & $\begin{array}{l}\text { Assessment criteria given to } \\
\text { students } \\
\text { Discussion of assessment } \\
\text { criteria }\end{array}$ \\
\hline & 5 & Coursework activities & $1,2,4,5,7$ & $\begin{array}{l}\text { Exemplar sections of report } \\
\text { Peer assessment of exemplars }\end{array}$ \\
\hline \multirow{3}{*}{$\begin{array}{l}\text { In- Task } \\
\text { Guidance }\end{array}$} & 6,7 & Coursework activities & $4,5,7$ & \\
\hline & $8 \& 9$ & Coursework activities & $4,5,7$ & Students completed drafts \\
\hline & 10,11 & $\begin{array}{l}\text { Drafts to be submitted } \\
\text { to tutor }\end{array}$ & $3,4,5,6,7$ & feedback of drafts \\
\hline \multirow{2}{*}{$\begin{array}{l}\text { Performance } \\
\text { Feedback }\end{array}$} & 12 & $\begin{array}{l}\text { Submission of } \\
\text { summative } \\
\text { coursework }\end{array}$ & 1,2 & Self-marking with submission \\
\hline & 14 & Summative feedback & $3,4,5,6,7$ & $\begin{array}{l}\text { Tutor Feedback (written and } \\
\text { 1:1 verbal) }\end{array}$ \\
\hline
\end{tabular}

\begin{tabular}{|l|l|}
\hline 1 & $\begin{array}{l}\text { Clarifies what good performance is (goals , criteria, expected } \\
\text { standards) }\end{array}$ \\
\hline 2 & Facilitates self-assessment in learning \\
\hline 3 & Delivers high quality information to students about their learning \\
\hline 4 & Encourages teacher and peer dialogue around learning \\
\hline 5 & Encourages positive motivational beliefs and self-esteem \\
\hline 6 & $\begin{array}{l}\text { Provides opportunities to close the gap between current and desired } \\
\text { performance }\end{array}$ \\
\hline 7 & $\begin{array}{l}\text { Provides information to teachers that can be used to help shape the } \\
\text { teaching }\end{array}$ \\
\hline
\end{tabular}


Table 3. Students' perceptions of criteria.

\begin{tabular}{|l|c|c|c|c|c|}
\hline Questionnaire Statement & & $\begin{array}{c}\% \\
\text { Agree / } \\
\text { Strongly } \\
\text { agree }\end{array}$ & $\begin{array}{c}\text { Mann- } \\
\text { Whitney } \\
\text { U- }\end{array}$ & $\begin{array}{c}\text { Significance } \\
\text { (1-tailed) }\end{array}$ & $\begin{array}{c}\text { Effect } \\
\text { size (r) }\end{array}$ \\
\hline $\begin{array}{l}\text { I was involved in discussing } \\
\text { assessment criteria at the start of } \\
\text { assessment tasks. }\end{array}$ & $\begin{array}{c}\text { control } \\
\text { intervention }\end{array}$ & $\begin{array}{c}76 \\
93\end{array}$ & 506 & 0.001 & 0.36 \\
\hline $\begin{array}{l}\text { I fully understood the assessment } \\
\text { criteria for my assignments }\end{array}$ & $\begin{array}{c}\text { control } \\
\text { intervention }\end{array}$ & $\begin{array}{c}78 \\
96\end{array}$ & 550 & 0.004 & 0.33 \\
\hline $\begin{array}{l}\text { At the start of an assignment I given } \\
\text { enough guidance so I fully } \\
\text { understood what to do. }\end{array}$ & $\begin{array}{c}\text { control } \\
\text { intervention }\end{array}$ & $\begin{array}{c}70 \\
75\end{array}$ & 625 & 0.037 & 0.20 \\
\hline $\begin{array}{l}\text { I fully understood what constituted } \\
\text { good performance for assignments }\end{array}$ & $\begin{array}{c}\text { control } \\
\text { intervention }\end{array}$ & $\begin{array}{c}90 \\
86\end{array}$ & 727 & 0.424 & 0.08 \\
\hline
\end{tabular}

Table 4: Students' perceptions of drafts.

\begin{tabular}{|l|l|l|l|l|l|}
\hline Questionnaire Statement & & $\begin{array}{l}\text { \% } \\
\text { Agree / } \\
\text { Strongly } \\
\text { agree }\end{array}$ & $\begin{array}{l}\text { Mann- } \\
\text { Whitney }\end{array}$ & $\begin{array}{l}\text { Significance } \\
\text { U- }\end{array}$ & $\begin{array}{l}\text { Effect } \\
\text { size (r) }\end{array}$ \\
\hline $\begin{array}{l}\text { I had opportunity for feedback from } \\
\text { tutors on draft sections of an } \\
\text { assignment }\end{array}$ & $\begin{array}{l}\text { control } \\
\text { intervention }\end{array}$ & $\begin{array}{l}60 \\
88\end{array}$ & 593 & 0.016 & 0.24 \\
\hline $\begin{array}{l}\text { I received useful feedback from tutors } \\
\text { on draft sections of an assignment }\end{array}$ & $\begin{array}{l}\text { control } \\
\text { intervention }\end{array}$ & $\begin{array}{l}78 \\
96\end{array}$ & 565 & 0.008 & 0.27 \\
\hline
\end{tabular}


Table 5. Students' perceptions of feedback.

\begin{tabular}{|l|c|c|c|c|c|}
\hline Questionnaire Statement & & $\begin{array}{c}\% \\
\text { Agree / } \\
\text { Strongly } \\
\text { agree }\end{array}$ & $\begin{array}{c}\text { Mann- } \\
\text { Whitney } \\
\text { U- }\end{array}$ & $\begin{array}{c}\text { Significance } \\
\text { (1-tailed) }\end{array}$ & $\begin{array}{c}\text { Effect } \\
\text { size (r) }\end{array}$ \\
\hline $\begin{array}{l}\text { The tutor's feedback was usually } \\
\text { encouraging- }\end{array}$ & $\begin{array}{c}\text { control } \\
\text { intervention }\end{array}$ & $\begin{array}{c}76 \\
88\end{array}$ & 643 & 0.053 & 0.19 \\
\hline $\begin{array}{l}\text { I understood the feedback I received } \\
\text { most of the time- }\end{array}$ & $\begin{array}{c}\text { control } \\
\text { intervention }\end{array}$ & $\begin{array}{c}89 \\
90\end{array}$ & 703.5 & 0.145 & 0.11 \\
\hline $\begin{array}{l}\text { Feedback often clearly related to the } \\
\text { assessment criteria- }\end{array}$ & $\begin{array}{c}\text { control } \\
\text { intervention }\end{array}$ & $\begin{array}{l}86 \\
89\end{array}$ & 775.5 & 0.432 & 0.02 \\
\hline $\begin{array}{l}\text { I received detailed feedback on } \\
\text { assignments- }\end{array}$ & $\begin{array}{c}\text { control } \\
\text { intervention }\end{array}$ & $\begin{array}{l}78 \\
93\end{array}$ & 653.5 & 0.057 & 0.01 \\
\hline $\begin{array}{l}\text { Once I have read the feedback I } \\
\text { understand why I got the mark I did- }\end{array}$ & $\begin{array}{c}\text { control } \\
\text { intervention }\end{array}$ & $\begin{array}{l}87 \\
89\end{array}$ & 782.5 & 0.454 & 0.18 \\
\hline $\begin{array}{l}\text { I received feedback quickly enough } \\
\text { for it to be useful- }\end{array}$ & $\begin{array}{c}\text { control } \\
\text { intervention }\end{array}$ & $\begin{array}{l}46 \\
84\end{array}$ & 469 & $<0.001$ & 0.37 \\
\hline $\begin{array}{l}\text { I had an opportunity to discuss } \\
\text { feedback with tutors }\end{array}$ & $\begin{array}{c}\text { control } \\
\text { intervention }\end{array}$ & $\begin{array}{l}73 \\
98\end{array}$ & 623.5 & 0.031 & 0.21 \\
\hline $\begin{array}{l}\text { The feedback I received has helped } \\
\text { me improve my learning }\end{array}$ & $\begin{array}{c}\text { control } \\
\text { intervention }\end{array}$ & $\begin{array}{c}54 \\
83\end{array}$ & 529 & 0.003 & 0.31 \\
\hline $\begin{array}{l}\text { If I didn't understand feedback I } \\
\text { sought guidance from my tutor }\end{array}$ & $\begin{array}{c}\text { control } \\
\text { intervention }\end{array}$ & $\begin{array}{c}51 \\
68\end{array}$ & 626 & 0.039 & 0.20 \\
\hline $\begin{array}{l}\text { When I received feedback I used it in } \\
\text { preparing my next assignment }\end{array}$ & $\begin{array}{c}\text { control } \\
\text { intervention }\end{array}$ & $\begin{array}{c}57 \\
79\end{array}$ & 618 & 0.027 & 0.22 \\
\hline
\end{tabular}


Table 6: Students' perceptions of Self-Regulated Learning abilities

\begin{tabular}{|l|c|c|c|c|c|}
\hline Questionnaire Statement & & $\begin{array}{c}\% \\
\text { Agree / } \\
\text { Strongly } \\
\text { agree }\end{array}$ & $\begin{array}{c}\text { Mann- } \\
\text { Whitney } \\
\text { U- }\end{array}$ & $\begin{array}{c}\text { Significance } \\
\text { (1-tailed) }\end{array}$ & $\begin{array}{c}\text { Effect } \\
\text { size (r) }\end{array}$ \\
\hline $\begin{array}{l}\text { INF1010 has improved my confidence } \\
\text { at completing assignments. }\end{array}$ & $\begin{array}{c}\text { control } \\
\text { intervention }\end{array}$ & $\begin{array}{c}62 \\
81\end{array}$ & 509 & 0.002 & 0.31 \\
\hline $\begin{array}{l}\text { I am now able to plan assignments by } \\
\text { myself. }\end{array}$ & $\begin{array}{c}\text { control } \\
\text { intervention }\end{array}$ & $\begin{array}{c}75 \\
81\end{array}$ & 539 & 0.023 & 0.23 \\
\hline $\begin{array}{l}\text { I am now able to confidently research } \\
\text { for assignments by myself. }\end{array}$ & $\begin{array}{c}\text { control } \\
\text { intervention }\end{array}$ & $\begin{array}{c}76 \\
88\end{array}$ & 572 & 0.011 & 0.25 \\
\hline $\begin{array}{l}\text { I am now able to select and apply } \\
\text { knowledge for assignments by myself. }\end{array}$ & $\begin{array}{c}\text { control } \\
\text { intervention }\end{array}$ & $\begin{array}{c}79 \\
89\end{array}$ & 602 & 0.023 & 0.22 \\
\hline $\begin{array}{l}\text { INF1010 has helped me to become a } \\
\text { more independent learner. }\end{array}$ & $\begin{array}{c}\text { control } \\
\text { intervention }\end{array}$ & $\begin{array}{c}68 \\
88\end{array}$ & 523 & 0.003 & 0.31 \\
\hline
\end{tabular}


Table7. Assessment marks.

\begin{tabular}{|c|c|c|c|c|c|c|}
\hline & year & $\mathrm{N}$ & Mean & Std. Deviation & $\begin{array}{l}\text { Significance (1- } \\
\text { tailed) }\end{array}$ & Effect size (r) \\
\hline \multirow[t]{2}{*}{ cw1 } & control & 54 & 53.65 & 8.951 & \multirow{2}{*}{0.068} & \multirow{2}{*}{0.15} \\
\hline & intervention & 50 & 56.76 & 12.023 & & \\
\hline \multirow[t]{2}{*}{ cw2 } & control & 53 & 57.43 & 7.702 & \multirow{2}{*}{0.235} & \multirow{2}{*}{0.07} \\
\hline & intervention & 50 & 55.84 & 13.866 & & \\
\hline
\end{tabular}




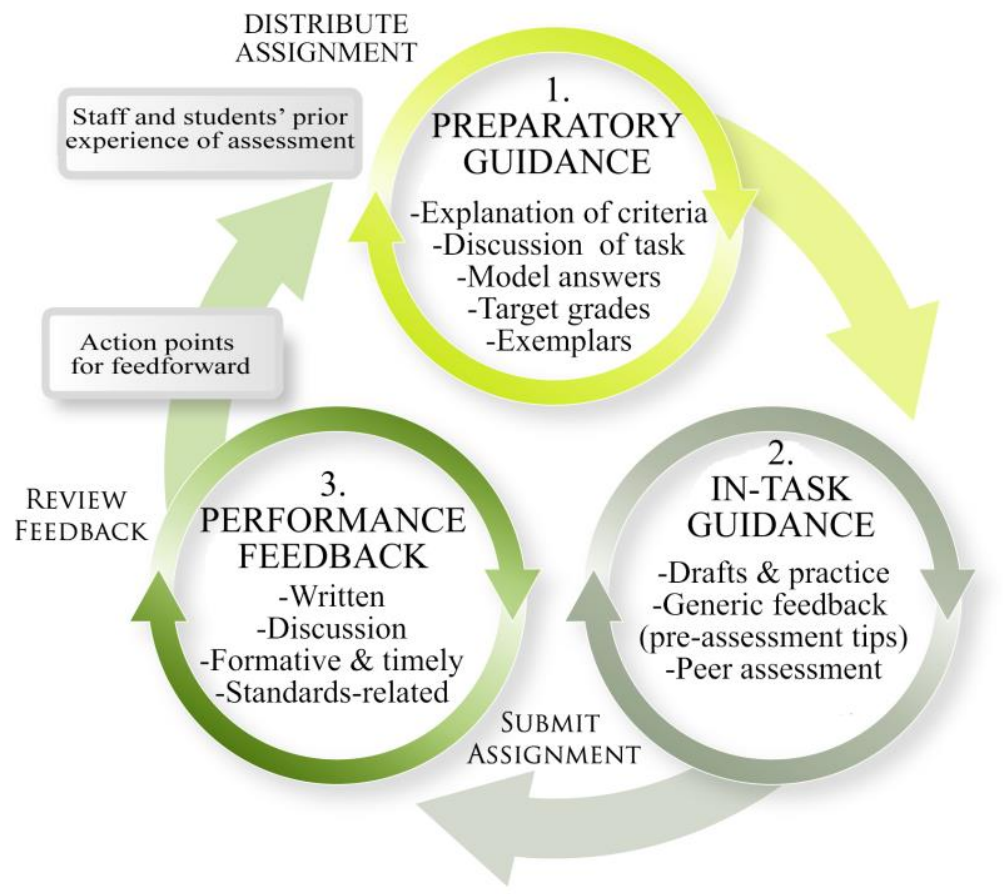

Figure 1. Dialogic Feedback Cycle in Further Education (DFC) Beaumont, O'Doherty \& Shannon (2011) 
Figure 2: Bar chart showing distribution of marks for coursework 1

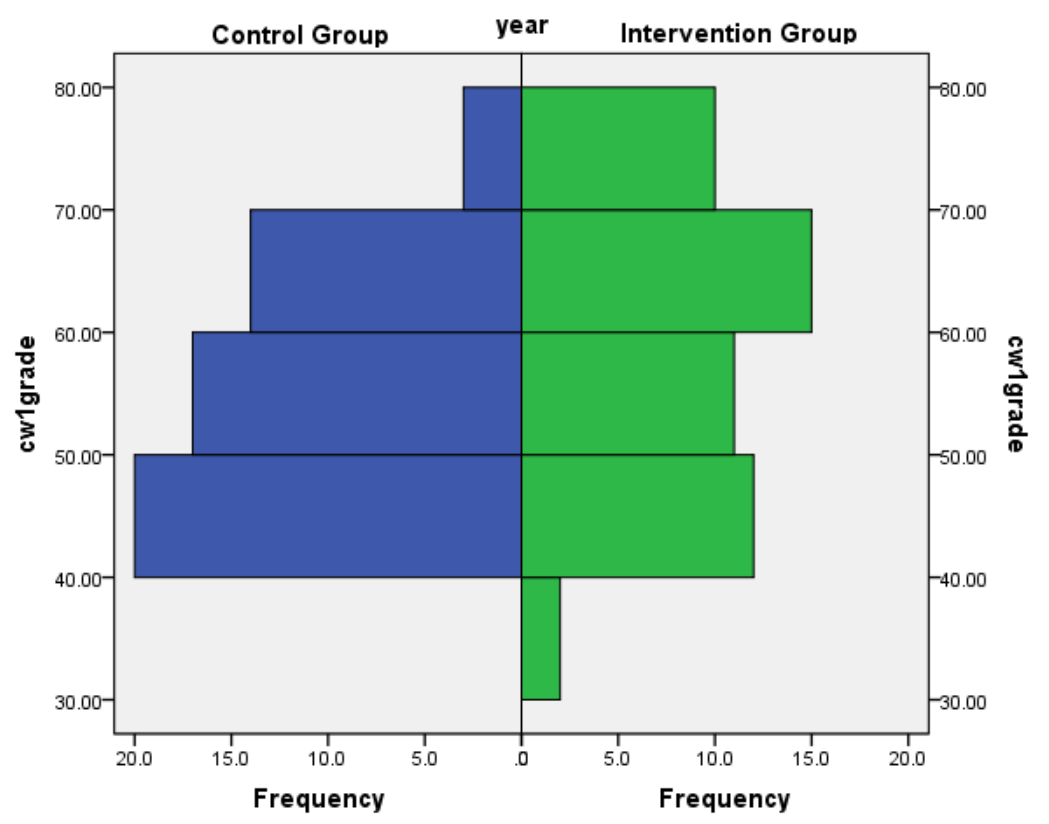

